\title{
13-Cis-Retinoic Acid-Induced Hyperglycemia in the Fresh Water Edible Crab, Oziothelphusa Senex Senex is mediated by Triggering Release of Hyperglycemic Hormone from Eyestalks
}

\section{Sreenivasula Reddy $\mathbf{P}^{1 *}$ and Srilatha $\mathbf{M}^{2}$}

${ }^{1}$ Department of Zoology, Sri Venkateswara University, Tirupati-517 502, India

${ }^{2}$ Department of Biotechnology, Sri Venkateswara University, Tirupati-517 502, India

\begin{abstract}
The present study was aimed to investigate the effect of 13-cis-retinoic acid (13-CRA) on hemolymph glucose levels in the fresh water edible crab, Oziothelphusa senex senex. Injection of 13-CRA significantly increased hemolymph glucose levels in a dose-dependent manner in intact crabs. Bilateral eyestalk ablation (ESX) resulted in significant decrease in hemolymph glucose levels. Injection of 13-CRA in to ESX crabs did not cause any significant changes in hemolymph glucose level as compared to ESX crabs suggesting that the effect of 13-CRA could be on the neuroendocrine system in the eyestalks increasing secretion of hyperglycemic hormone. To test this hypothesis, eyestalks were collected from control and 13-CRA injected crabs, and tested for hyperglycemic effect and also for the hyperglycemic hormone levels. The levels of hyperglycemic hormone and the hyperglycemic effect were significantly low in the eyestalks collected from 13-CRA injected crabs when compared with eyestalks from control crabs. From results, it is hypothesized that 13-CRA-induced hyperglycemia in the crab, $O$. senex, is mediated by triggering the release of hyperglycemic hormone from the eyestalk.
\end{abstract}

Keywords: 13-cis-retinoic acid; Eyestalk ablation; Hyperglycemia; Hemolymph glucose, Oziothelphusa senex senex.

\section{Introduction}

In crustaceans, glucose homeostasis is primarily under the control of an eyestalk hormone, namely crustacean hyperglycemic hormone $(\mathrm{CHH})$. Crustacean hyperglycemic hormone as a diabetogenic factor was first reported by Abramowitz et al. [1], within eyestalks of decapod crustaceans. Since then, the chemical nature, mode of action, and the target tissues of $\mathrm{CHH}$ have been extensively studied in several crustaceans [2-5]. The action of $\mathrm{CHH}$ in inducing hyperglycemia is mainly through mobilization of glucose from the tissue carbohydrate pools [6]. It has been reported that $\mathrm{CHH}$ stimulates glycogenolysis by activating glycogen phosphorylase in both muscle and hepatopancreas $[2,7]$.

Retinoic acids (RA) including 9-cis-retinoic acid (9-CRA) and 13-cis-retinoic acid (13-CRA) and all-trans-retinoic acid (ATRA) are the metabolites of the vitamin A. Retinoids render their biological activity by binding to nuclear receptors in vertebrates. cis-retinoic acids like 9-CRA and 13-CRA interacts with both retinoic acid receptors (RAR $\alpha, \beta, \gamma$ ) and retinoid X receptor (RXR), whereas ATRA mainly interacts with the RARs [8]. It was reported earlier that administration of cis-retinoic acid increases insulin release in cultured RINm5F cells $[9,10]$. The antidiabetic effects of retinoids in human skeletal muscle [11] and diabetic rodents [12] are accepted to be the mediated through the RXR/RAR heterodimer, and RXR homodimer.

In several crustaceans endogenous retinoic acid has been discovered [13] though it is not recognized as a functional hormone. Although there are sporadic reports on the identification of retinoic acid in crustaceans [14], there is little information available on the role of retinoic acid in the regulation of physiology. Recently, we have reported hyperglycemia in the freshwater crab Oziothelphusa senex senex after 9-CRA administration [15]. In as much as (a) RA is identified in the crustacean eyestalks and in circulation [13], (b) RXR was discovered in the eyestalks of $O$. senex, and (c) the eyestalks are the major site of $\mathrm{CHH}$ secretion [2], the present study was undertaken to examine the possibility that 13-CRA has any role in regulating hemolymph glucose level in the crab O. senex senex and if so, to determine whether it has any effect on $\mathrm{CHH}$ in the eyestalks.

\section{Materials and Methods}

\section{Collection and maintenance of animals}

Intact, intermolt (Stage $\mathrm{C}_{4}$ ) adult male crabs, Oziothelphusa senex senex Fabricius, with a body weight of $30 \pm 3 \mathrm{~g}$ and carapace width of 36 $\pm 3 \mathrm{~mm}$ were collected from the rice fields and irrigation canals around Tirupati $\left(13^{\circ} 36^{\prime} \mathrm{N}, 79^{\circ} 25^{\prime} \mathrm{E}\right)$, Andhra Pradesh, India. The animals were housed 6-8 per glass aquaria (length: width: height $=60: 30: 30 \mathrm{~cm}$ ) with $40 \mathrm{~L}$ sand-filtered tap water (Salinity: $0.5 \mathrm{ppt}$ ) and transferred to fresh water every day. They were acclimatized to the laboratory conditions (temperature $28 \pm 1^{\circ} \mathrm{C}$ and12:12 h; light: dark cycle) for 7 days before use. The crabs were fed with sheep meat ad libitum once daily. Feeding was stopped one day before the commencement of the experiment to avoid changes due to prandial activity.

\section{Test chemical}

13-cis-retinoic acid (13-CRA; chemical purity $\geq 98 \%$ HPLC) was purchased from Sigma Chemical Company (St. Louis, MO, USA). 13CRA was dissolved in acetone and then one aliquot of this solution was mixed with nine aliquots of crustacean saline $(0.2 \mathrm{M} \mathrm{NaCl}, 5.4 \mathrm{mM}$

*Corresponding author: Sreenivasula Reddy, Department of Zoology, Sri Venkateswara University, Tirupati-517 502, India, Tel: +91-0877-2249320; E-mail: psreddy1955@gmail.com

Received April 10, 2015; Accepted May 26, 2015; Published June 30, 2015

Citation: Sreenivasula Reddy P, Srilatha M (2015) 13-Cis-Retinoic Acid-Induced Hyperglycemia in the Fresh Water Edible Crab, Oziothelphusa Senex Senex is mediated by Triggering Release of Hyperglycemic Hormone from Eyestalks. J Aquac Res Development 6: 356. doi:10.4172/2155-9546.1000356

Copyright: (c) 2015 Sreenivasula Reddy P, et al. This is an open-access article distributed under the terms of the Creative Commons Attribution License, which permits unrestricted use, distribution, and reproduction in any medium, provided the original author and source are credited. 
Citation: Sreenivasula Reddy P, Srilatha M (2015) 13-Cis-Retinoic Acid-Induced Hyperglycemia in the Fresh Water Edible Crab, Oziothelphusa Senex Senex is mediated by Triggering Release of Hyperglycemic Hormone from Eyestalks. J Aquac Res Development 6: 356. doi:10.4172/21559546.1000356

Page 2 of 5

$\mathrm{KCl}, 2.6 \mathrm{mM} \mathrm{MgCl}, 13.5 \mathrm{mM} \mathrm{CaCl}, 5.6 \mathrm{mM}$ maleate, $10.8 \mathrm{mM}$ Tris; $\mathrm{pH}$ 7.4) [16] to produce the final dose for injection.

\section{Experimental Design}

Three experiments were conducted. Experiment 1 was conducted to determine the dose of 13-CRA that induces maximum hyperglycemia in intact adult male crabs. Experiment 2 was performed to determine the time-course of action of 13-CRA in inducing hyperglycemia. Experiments 3, 4 and 5 were conducted to establish whether eyestalk hyperglycaemic hormone is involved in 13-CRA-induced hyperglycemia.

In experiment 1 , intact adult male crabs were injected with different doses of 13-CRA through the base of the chelae with a micro-syringe (Hamilton make) in $10 \mu \mathrm{l}$ volume. Control crabs were injected with 10 $\mu \mathrm{l}$ crustacean saline. Hemolymph was collected from the crabs $2 \mathrm{~h}$ after injection and analysed for sugar levels.

In experiment 2 , intact adult male crabs were injected with $25 \mu \mathrm{g}$ retinoic acid/g live mass. This dose was selected based on the results of experiment 1 (see below). Hemolymph was withdrawn from injected crabs at different time points $(30,60,120$, and $360 \mathrm{~min})$ and used for glucose quantification as described in experiment 1.

In experiment 3 , both eyestalks were removed (in order to deprive the eyestalk hormones) from the crabs by cutting off the stalks at their bases at the arthrodial membrane without prior ligation, but with cautery of the wound after operation. We routinely achieve more than $95 \%$ survival of the crabs following the operation. Twenty four hours after eyestalk ablation, eyestalkless crabs (ESX) were then injected with $25 \mu \mathrm{g}$ retinoic acid/g live mass. Hemolymph was collected from ESX crabs, $2 \mathrm{~h}$ after 13-CRA injection and used for glucose quantification. The dose of 13-CRA and time-point of hemolymph collection were selected based on the results of experiment 1 and 2 (see below).

In experiment 4 , forty eight intact adult male crabs were divided into six equal groups. Crabs in group I served as control and the animals in group II served as saline injected controls. Animals in groups III and IV were injected with either saline $(25 \mu \mathrm{l})$ or $25 \mu \mathrm{g}$ retinoic acid/g live mass respectively. Two hours after injection, both eyestalks were collected from crabs in groups III and IV and eyestalk extracts were prepared by homogenizing the eyestalk neural tissue in crab physiological saline and then centrifuging at $10,000 \times \mathrm{g}$ for 10 $\min$ at $4^{\circ} \mathrm{C}$. The supernatant was used for injections. Crabs in groups $\mathrm{V}$ and VI were injected with $25 \mu \mathrm{l}$ of extract (two eyestalk equivalents per crab) prepared using eyestalks collected from crabs in groups III and IV respectively. Hemolymph was collected from control, saline injected control and eyestalk extract injected crabs $2 \mathrm{~h}$ after injection and glucose levels were determined.

In experiment 5 , crabs were injected with either saline or $25 \mu \mathrm{g}$ retinoic acid/g live mass. Two hours after injection, eyestalks were collected from saline injected and 13-CRA injected crabs and sinus glands were isolated. Following HPLC of sinus gland sample [17], collected fractions were assayed for $\mathrm{CHH}$. $\mathrm{CHH}$ levels were measured using ELISA. The details of ELISA were described elsewhere $[15,18]$. The polyclonal antibodies for $O$. senex $\mathrm{CHH}$ raised in our laboratory were for the ELISA.

\section{Hemolymph glucose determination}

A $10 \mu$ hemolymph sample was collected from the arthrodial membrane of coxa of third pair of walking leg using a micro-syringe and mixed with $250 \mu \mathrm{l}$ of distilled water and then stored at $-80^{\circ} \mathrm{C}$.
Glucose concentration was measured enzymatically using the glucose oxidase assay kit (Sigma Chemical Co. St. Louis, MO, USA). The assay protocol essentially followed the one provided by the manufacturer.

\section{Statistical analysis}

Data were analyzed by one-way ANOVA followed by Tukey's test using SPSS (Student version 7.5, SPSS Inc, Chertsey, UK). Differences were considered to be significant when $p<0.05$. All data are reported as mean \pm S.D.

\section{Results}

\section{Effect of 13-cis-retinoic acid on hemolymph glucose levels of intact crabs}

Injection of 13CRA into intact crabs resulted in significant hyperglycemia in a dose-dependent manner, whereas injection of physiological saline did not cause any significant effect on hemolymph glucose levels (Figure 1). At doses between $10 \mu \mathrm{g} / \mathrm{g}$ live mass and $25 \mu \mathrm{g} / \mathrm{g}$ live mass, the effect was statistically significant and dose-dependent. Doses lower than $10 \mu \mathrm{g} / \mathrm{g}$ live mass, however, retinoic acid did not elicit any hyperglycemic response and doses greater than $25 \mu \mathrm{g} / \mathrm{g}$ live mass exhibited a saturated response in inducing hyperglycemia. In the subsequent experiments, $25 \mu \mathrm{g} / \mathrm{g}$ live mass was selected as injection dose.

A time course action of 13CRA-induced hyperglycemia is presented in Figure 2. Hemolymph glucose levels increased significantly $(p<0.01)$ within $30 \mathrm{~min}$ after 13-CRA injection and reached a highest peak in 2 $\mathrm{h}$; thereafter, a decline in the hemolymph glucose levels were observed. The hemolymph glucose level was almost normal at $6 \mathrm{~h}$ post-injection.

Effect of eyestalk ablation and injection of 13-CRA on hemolymph glucose level in eyestalk-ablated crabs

Bilateral eyestalk ablation resulted in a significant decrease $(-49.63 \%)$ in hemolymph glucose level in the crab O. senex (Figure 3). Injection of 13-CRA ( $25 \mu \mathrm{g} / \mathrm{g}$ live mass) into ESX crabs resulted in no significant change in the levels of hemolymph glucose when compared with ESX crabs (Figure 3).

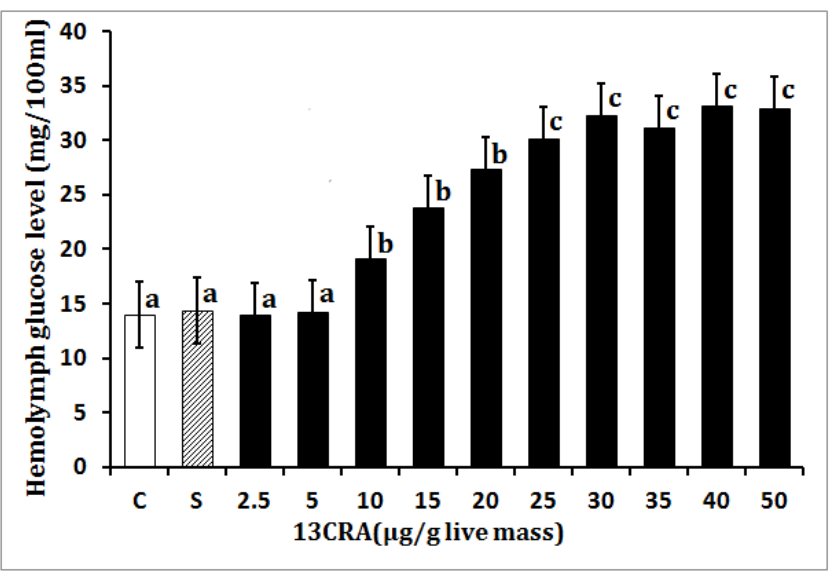

Figure 1: Dose dependent effects of 13CRA on the hemolymph glucose levels in intact crabs. Hemolymph was collected from animals for glucose quantification before (open bar; $\mathrm{C}$ : Control) and $2 \mathrm{~h}$ after injection with saline (striped bar; S) or 13CRA. Each bar represents a mean \pm SD of 8 individuals. Bars with different superscript differ significantly from each other at $p<0.05$ 
Citation: Sreenivasula Reddy P, Srilatha M (2015) 13-Cis-Retinoic Acid-Induced Hyperglycemia in the Fresh Water Edible Crab, Oziothelphusa Senex Senex is mediated by Triggering Release of Hyperglycemic Hormone from Eyestalks. J Aquac Res Development 6: 356. doi:10.4172/21559546.1000356

Page 3 of 5

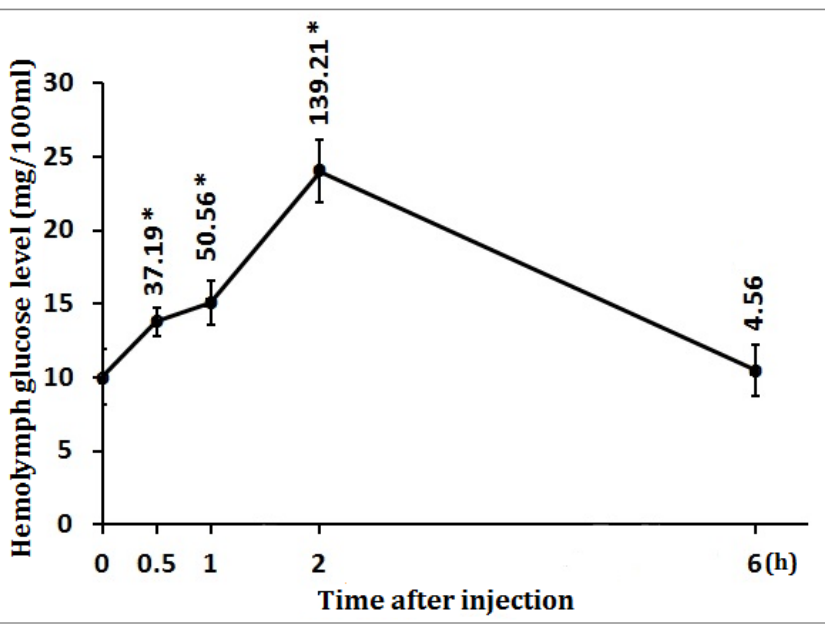

Figure 2: Time course action of 13-CRA-induced hyperglycemia in intact crabs. Hemolymph was collected from intact crabs after injection of retinoic acid $(25 \mu \mathrm{g} / \mathrm{g}$ live mass), at the time points indicated for glucose quantification. Each point represents a mean \pm S.D. of 8 individuals. Values in parenthesis represent percent change from control $(0 \mathrm{~h}) .{ }^{*} p<0.05$.

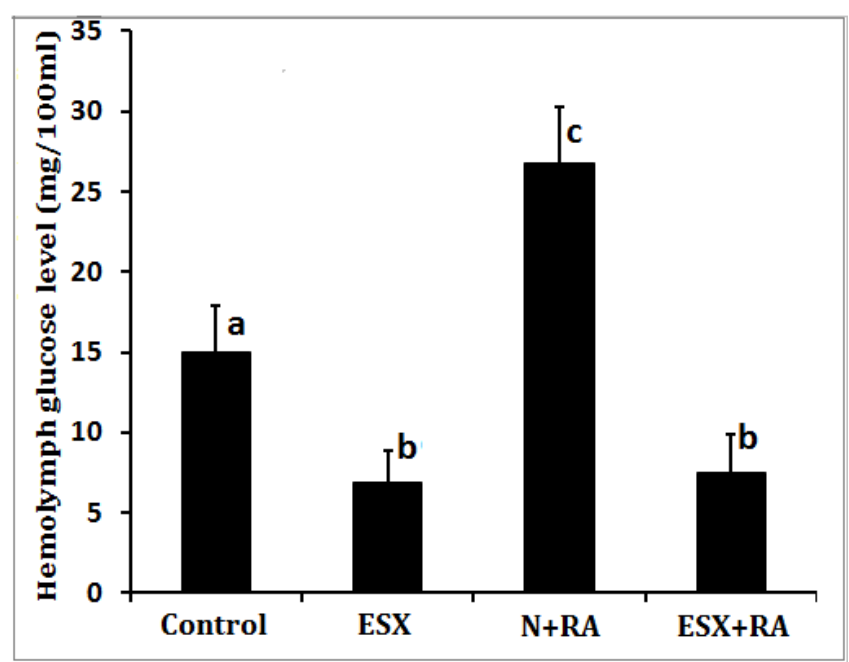

Figure 3: Effect of eyestalk ablation (ESX) and injection of 13-CRA in to normal and ablated crabs on hemolymph glucose levels in $O$. senex. Each bar represents a mean \pm S.D. of 8 individuals. Bars with different superscripts differ significantly from each other at $p<0.05$.

\section{Effect of 13-CRA on hyperglycemic activity and $\mathrm{CHH}$ content in the eyestalks}

Injection of eyestalk extract of intact crabs produced significant hyperglycemia (83.05\% above control) (Table 1). Injection of either saline $(25 \mu \mathrm{l})$ or extracts of eyestalks collected from 13-CRA injected crabs did not cause any significant change in hemolymph glucose concentration when compared with uninjected crabs (Table 1).

Eyestalks of control crabs contained $76.43 \pm 8.93 \mathrm{fmol} \mathrm{CHH}-$ immunoreactive peptide per sinus gland. Eyestalks of crabs injected with 13-CRA ( $25 \mu \mathrm{g} / \mathrm{g}$ live mass) contained significantly less (-62.98\%) $\mathrm{CHH}$-immunoreactive peptide than in the eyestalks of control crabs (Table 2).

\begin{tabular}{|l|c|}
\hline Treatment & Hemolymph glucose level $(\mathbf{m g} / \mathbf{1 0 0} \mathbf{~ m l})$ \\
\hline Control & $15.75 \pm 1.86$ \\
\hline Saline injected & $16.23 \pm 1.69$ \\
& $(3.05)$ \\
\hline Eyestalk extract from control injected & $28.86^{\star} \pm 2.35$ \\
& $(83.05)$ \\
\hline Eyestalk extract from 13CRA injected & $18.45 \pm 2.46$ \\
& $(17.14)$ \\
\hline
\end{tabular}

Values are mean \pm S.D of 8 crabs.

Values in parentheses are $\%$ change from control. ${ }^{*} p<0.05$.

Table 1: Effect of 13-CRA on hemolymph glucose concentrations in crabs injected with saline or various eyestalk extracts.

\begin{tabular}{|l|c|}
\hline Treatment & CHH peptide level (fmol/sinus gland) \\
\hline Control & $76.43 \pm 8.93$ \\
\hline 13-CRA injected & $28.29^{*} \pm 7.86$ \\
& $(-62.98)$ \\
\hline
\end{tabular}

Values are mean $\pm S D n=5$ for each group.

Values in parentheses are $\%$ change from control. ${ }^{*} p<0.05$.

Table 2: Effect of 13-CRA on levels of $\mathrm{CHH}$ peptides in eyestalks.

\section{Discussion}

In the crab, O. senex, bilateral eyestalk ablation resulted in significant decrease in the hemolymph glucose levels as compared to intact crabs. Injection of 13-CRA significantly elevated hemolymph glucose levels in intact crabs in a dose-dependent manner. An elevation in glucose concentration in the hemolymph of O. senex following 13-CRA injection is apparently mediated by the eyestalk $\mathrm{CHH}$ hormone, since an increase in the hemolymph glucose concentration following 13-CRA injection was absent after eyestalks were ablated. Zou and Bonvilliain [19] and Reddy and Sainath [15] also reported hyperglycemia in the crabs $U$. pugilator and $O$. senex respectively after 9-CRA administration. Both 13-CRA and 9-CRA most likely rendered their hyperglycemic action through stimulating the release of $\mathrm{CHH}$ from the eyestalk neuroendocrine cells to the circulation, since hyperglycemia was observed only in intact crabs but not in eyestalkablated crabs. From the results it can be hypothesized that CRA triggers the release of $\mathrm{CHH}$ from the sinus gland of the eyestalks. This hypothesis was further supported by the fact that hyperglycemic activity of the eyestalk extracts of the 13CRA injected crabs was less than that of the control crabs. Direct supporting evidence for this hypothesis is provided by the present studies, in which it was shown that the levels of $\mathrm{CHH}$-immuno-reactive peptides were significantly reduced in the eyestalks of the crabs received 13CRA when compared to the $\mathrm{CHH}$ levels in the eyestalks of control crabs. These results strongly suggest that hyperglycemia caused by 13-CRA in intact crabs was due to the triggering release of $\mathrm{CHH}$ in the crab.

It is well known that alterations in the circulatory levels of $\mathrm{CHH}$ occurred during different stress conditions, including cold shock [20], parasite infection [21], exposure to pesticides [22], and heavy metals [23]. It is also known that elevated circulating titres of $\mathrm{CHH}$ were reported to occur following exposure to several environmental stressors [24,25] in intact but not in eyestalk ablated crabs, suggesting stress-induced hyperglycemia is $\mathrm{CHH}$ mediated response [26-29].

The role of RA in the regulation of glucose metabolism in vertebrates is well established [14]. Retinoids have been implicated in both stimulation of insulin secretion and expression of the glucose transporter 2 gene [10]. Further, retinoids are believed to exert their effects through the retinoic acid receptor/PPAR $\gamma$ heterodimer [11, 
Citation: Sreenivasula Reddy P, Srilatha M (2015) 13-Cis-Retinoic Acid-Induced Hyperglycemia in the Fresh Water Edible Crab, Oziothelphusa Senex Senex is mediated by Triggering Release of Hyperglycemic Hormone from Eyestalks. J Aquac Res Development 6: 356. doi:10.4172/21559546.1000356

12] or retinoic acid receptor (RAR) homodimer [9]. However, such mechanisms in crustaceans are yet to be investigated.

In crustaceans, endogenous RA [13] and a nuclear RAR homologue have been detected [30, 31]. The RAR isolated from the crab has been found to bear a close similarity to vertebrate RARs in the ligand-binding domain. To date, RXR was identified from the ovaries of C. pugilator, G. lateralis, M. japonicas, F. chinensis, C. maenas, Scylla serrata and Daphnia magna [32-38]. Recently, RXR has been also identified in the eyestalks of Callinectes sapidus [39] O. senex [40] and M. nipponence [41]. Reduction in mRNA levels for RXR and for vitellogenin in the crab, C. maenas after treatment with RXR dsRNA [36] and fluctuations in expression of RXR mRNA in ovaries during reproduction [30] suggests RA acts as reproductive hormone. RAs in crustaceans are also identified as morphogens involved in the limb bud regeneration and morphogenesis $[13,14]$. RXR has also been identified for which terpenoids can serve as ligands [42]. It was also established that RXR binds with ecdysteroid receptor (EcR) and form a heterodimer $[36,42]$. This RXR-EcR complex may bind with RA or ecdysteroid $(\mathrm{EcD})$ or methyl farnesoate $(\mathrm{MF})$ and form a heterotrimeric complex (RXR-EcR-RA/EcD/MF) thereby regulate a range of physiological facets in crustaceans. The potential of retinoids in regulating various physiological aspects in crustaceans should now be open for analysis.

\section{Conclusion}

On the basis of the results obtained in this study it can be concluded that injection of 13-CRA resulted in significant hyperglycemia in intact crabs, but not in eyestalk ablated crabs suggesting that 13-CRA induced hyperglycemia is mediated through eyestalk hyperglycemic hormone. The levels of hyperglycemic hormone and the hyperglycemic effect was significantly lower in the eyestalks collected from 13-CRA injected crabs when compared with eyestalks from control crabs, strongly suggesting that retinoic acid act, at least in part, by triggering the secretion of hyperglycemic hormone from the eyestalk.

\section{Acknowledgment}

The authors are grateful to the Head, Department of Biotechnology, S.V. University, Tirupati, for providing facilities. We thank Professor K.V.S. Sarma, Department of Statistics, S.V. University, Tirupati, for the statistical analysis of data and Mr. S. Umasankar for maintaining the crabs in the laboratory. This research was supported by a research grant from DST to PSR.

\section{References}

1. Abramowitz AA, Hisaw FL, Papand DN (1944) The occurrence of a diabetogenic factor in the eyestalks of crustaceans. Biol Bull 86: 1-5.

2. Fanjal-Moles ML (2006) Biochemical and functional aspects of crustacean hyperglycemic hormone in decapod crustaceans. Comp Biochem Physiol 142: 390-400

3. Van Herp F (1998) Molecular, cytological and physiological aspects of the crustacean hyperglycemic hormone family.

4. Chang ES, Chang SA, Mulder EP (2001) Hormones in the lives of crustaceansAn overview. Am Zool 41: 1090-1097.

5. Webster SG, Keller R, Dircksen H(2012) The $\mathrm{CHH}$-super family of multifunctional peptide hormones controlling crustacean metabolism, osmoregulation, moulting, and reproduction. Gen Comp Endocrinol 175: 217-233.

6. Santos EA, Keller R (1993) Crustacean hyperglycemic hormone $(\mathrm{CHH})$ and the regulation of carbohydrate metabolism- current perspectives. Comp Biochem Physiol A 106: 405-411.

7. Davidson VL, Sittman DM (1999) Biochemistry. Lippincott, William\&Wilkins, Philadelphia, pp, 333-340.

8. Chambon $P$ (1996) A decade of molecular biology of retinoic acid receptors. FASEB J 10: 940-954.

9. Chertow BS, Driscoll HK, Goking NQ, Primerano D, Cordle MB, et al. (1997)
Retinoid-X receptor and the effects of 9-cis-retinoic acid on insulin secretion from RINm5F cells. Metabolism 46: 656-660.

10. Blumentrath J, Neye H, Verspohl EJ (2001) Effects of retinoids and thiazolidiones on proliferation, insulin release, insulin mRNA, GLUT 2 transporter protein and mRNA of INS-1 cells. Cell Biochem Funct 19: 159-169.

11. Cha BS, Ciaraldi TP, Carter L, Nikoulina SE, Mudaliar S, et al. (2001) Peroxisome proliferator activated receptor (PPAR) $y$ and retinoid $X$ receptor (RXR) agonists have complementary effects on glucose and lipid metabolism in human skeletal muscle. Diabetologia 44: 444-452.

12. Singh AH, Liu S, Crombie DL, Boehm M, Leibowitz MD, et al. (2001) Differential effects of retinoids and thiazolidiones on metabolic gene expression in diabetic rodents. Mol Pharmacol 59: 765-773.

13. Hopkins $P$ (2001) Limb regeneration in the fiddler crab, Uca pugilator-hormonal and growth factor control. Am Zool 41: 389-398.

14. Theodosiou M, Laudet V, Schubert M (2010) From carrot to clinic: an overview of the retinoic acid signalling pathway. Cell Mol Life Sci 67: 1423-1445.

15. Reddy PS, Sainath SB (2008) Effect of retinoic acid on hemolymph glucose regulation in the fresh water edible crab, Oziotelphusa senex senex. Gen Comp Endocrinol 155: 496-502

16. Van Harreveld A (1936) A physiological solution for freshwater crustaceans Proc Soc Exp Biol Med 34: 428-432.

17. Reddy PR, Reddy PS (2006) Isolation and characterization of three cDNAs encoding $\mathrm{CHH}$-family peptides from the crab, Oziotelphusa senex senex. Biotechnology 5: 436-442.

18. Chang ES, Keller R, Chang SA (1998) Quantification of crustacean hyperglycemic hormone by ELISA in hemolymph of the lobster, Homarus americanus, following various stresses. Gen Comp Endocrinol 111: 359-366.

19. Zou E, Bonvilliain R (2003) Effects of 9-cis and all-trans-retinoic acids on blood glucose homeostasis in the fiddler crab, Uca pugilator. Comp Biochem Physio C 136: 199-204.

20. Kuo CM, Yang YH (1999) Hyperglycemic responses to cold shock in the freshwater giant prawn, Macrobrachium rosenbergii. J Comp Physiol 169: 49-54.

21. Stentiford GD, Chang ES, Chang SA, Neil NM (2001) Carbohydrate dynamics and the crustacean hyperglycemic hormone $(\mathrm{CHH})$ - effects of parasitic infection in Norway lobster Nephrops norvegicus. Gen Comp Endocrinol 121: 13-22.

22. Fingerman M, MHanumante MM, Deshpande UD, Nagabhushanam $R$ (1981) Increase in the total reducing substances in the hemolymph of the fresh water crab Barytelphusa guerini, produced by a pesticide DDT and an indolealkylamine (serotonin). Experientia 37: 178-179.

23. Reddy, PS, Reddy, PR, Sainath, SB (2011) Cadmium and mercury-induced hyperglycemia in the fresh water crab, Oziotelphusa senex senex: Involvement of neuroendocrine system. Ecotoxicol Env Saf 74: 279-283.

24. Durand F, Devillers N, Lallier FH, Regnault M (2000) Nitrogen excretion and change in blood components during emersion of the subtidal spider crab Maja squinado (L). Comp Biochem Physiol A 127: 259-271.

25. Lorenzon S, Pasqual P, Ferrero EA (2002)Different bacterial lipopolysaccharides as toxicants and stressors in the shrimp, Palaemon elegans. Fish Shellfish Immunol 13: 27-45.

26. Reddy PS, Bhagyalakshmi A (1994) A change in oxidative metabolism in selected tissues of the crab Scylla serrata in response to cadmium toxicity. Ecotoxicol Environ Saf 29: 255-264.

27. Lorenzon S, Francese M, Ferrero EA (2000) Heavy metal toxicity and differential effects on the hyperglycemic stress responses in the shrimp Palaemon elegans. Arch Environ Contam Toxicol 39: 167-176.

28. Lorenzon S, Edoma P, Giulianini PG, Mettulio R, Ferrero EA (2004) Variations of crustacean hyperglycemic hormone $(\mathrm{CHH})$ level in the eyestalk and hemolymph of the shrimp Palaemon elegans following stress. J Exp Biol 207 4205-4213.

29. Lorenzon S, Edomi P, Giulianini PG, Mettulio R, Ferrero EA (2005) Role of biogenic amines and $\mathrm{CHH}$ in the crustacean hyperglycemic stress response. Exp Biol 208: 3341-3347.

30. Durica DS, Wu X, Anilkumar G, Hopkins PM, Chung ACK (2002) Characterization of crab EcR and RXR homologs and expression during limb regeneration and oocyte maturation. Mol Cell Endocrinol 189: 59-76. 
Citation: Sreenivasula Reddy P, Srilatha M (2015) 13-Cis-Retinoic Acid-Induced Hyperglycemia in the Fresh Water Edible Crab, Oziothelphusa Senex Senex is mediated by Triggering Release of Hyperglycemic Hormone from Eyestalks. J Aquac Res Development 6: 356. doi:10.4172/21559546.1000356

Page 5 of 5

31. Chung AC, Durica DS, Clifton SW, Roe BA, Hopkins PM (1998a) Cloning of crustacean ecdysteroid receptor and retinoid-X receptor gene homologs and elevation of retinoid-X receptor mRNA by retinoic acid. Mol Cell Endocrinol 139: 209-227.

32. Chung AC, Durica DS, Hopkins PM (1998b) Tissue-specific patterns and steady-state concentrations of ecdysteroid receptor and retinoid-X recepto mRNA during the molt cycle of the fiddler crab, Uca (Celuca) pugilator. Gen Comp Endocrinol 109: 375-389.

33. Kim HW, Donald SGL, Mykles L (2005) Ecdysteroid-responsive genes, RXR and E75, in the tropical land crab, Gecarcinus lateralis - differential tissue expression of multiple RXR isoforms generated at three alternative splicing sites in the hinge and ligand-binding domains. Mol Cell Endocrinol 242: 80-95.

34. Asazuma H, Nagata S, Kono M, Nagasawa $H$ (2007) Molecular cloning and expression analysis of ecdysone receptor and retinoid $X$ receptor from the kuruma prawn, Marsupenaeus japonicus. Comp Biochem Physiol 148: 139-150.

35. Priya TAJ, Lia F, Zhanga J, Wanga B, Zhaoa C, Xiang J (2009) Molecular characterization and effect of RNA interference of retinoid $X$ receptor (RXR) on E75 and chitinase gene expression in Chinese shrimp Fenneropenaeus chinensis. Comp Biochem Physiol B 153: 121-129.

36. Nagaraju GPC, Rajitha B, Borst DW (2011) Molecular cloning and sequence of retinoid $X$ receptor in the green crab Carcinus maenas - a possible role in female reproduction. J Endocrinol 210: 379-390.
37. Girish BP, Swetha CH, Reddy PS (2015) Induction of ecdysteroidogenesis and methyl farnesoate synthesis and expression of ecdysteroid receptor and retinoid $\mathrm{X}$ receptor in the hepatopancreas and ovary of the giant mud crab Scylla serrata by melatonin. Gen Comp Endocrinol.

38. Wang YH, Wang G, LeBlanc GA (2007) Cloning and characterization of the retinoid $\mathrm{X}$ receptor from a primitive crustacean Daphnia magna. Gen Comp Endocrinol 150: 309-318.

39. Techa S, Chung JS (2013) Ecdysone and retinoid-X receptors of the blue crab Callinectes sapidus - cloning and their expression patterns in eyestalks and Y-organs during the molt cycle. Gene 527: 139-153.

40. Girish BP, Swetha CH, Reddy PS (2015) Expression of RXR, EcR, E75 and VtG mRNA levels in the hepatopancreas and ovary of the freshwater edible crab, Oziothelphusa senex senex (Fabricius, 1798) during differen t vitellogenic stages. Sci Nat 102:1272.

41. Li Z, Wang WQ, Zhang EF, Qiu GF (2014) Identification of spliced mRNA isoforms of retinoic acid receptor (RXR) in the oriental fresh water prawn Macrobrachium nipponence. Genet Mol Res 13: 3914-3926.

42. Hopkins PM, Durica D, Tracy W (2008) RXR isoforms and endogenous retinoids in the fiddler crab, Uca pugilator. Comp Biochem Physiol A 151: 602-614. 